\title{
CHARACTERIZATION OF XILANASE ENZYMES OF BACILLUS SUBTILIS AS A BIOBLEACHING AGENT
}

\author{
Devita Sulistiana ${ }^{1}$, Dian Puspita Anggraini' ${ }^{2}$, Dwi Kameluh Agustina ${ }^{3}$ \\ ${ }^{1,2,3}$ Universitas Islam Balitar \\ Jl. Majapahit No.4 Kota Blitar \\ devitasulistiana17@gmail.com
}

DOI: $10.21107 / j p s . v 8 i 1.8639$

\begin{abstract}
Xylanase can be used as an alternative material in the pulp bleaching process to reduce the use of chemicals in the paper industry. Bacillus subtilis is a type of bacteria that can produce xylanase. Xylanase characterization is needed to determine the maximum activity that will be used in the pulp bleaching process. This study aims to determine the xylanase characterization of Bacillus subtilis in terms of optimal pH, optimal temperature, carbon source, and optimal nitrogen source. The research material used was a pure culture of Bacillus subtilis bacteria obtained from the Biochemistry Laboratory of the Department of Chemistry, Faculty of Mathematics and Natural Sciences, Brawijaya University. The characterization of the xylanase enzyme was carried out using the RAL method. The results of characterization of the determination of $\mathrm{pH}$, temperature, carbon source, and nitrogen xylanase source from Bacillus subtilis showed that the optimum conditions for xylanase were at $\mathrm{pH} 7$ with a maximum activity of $5.085 \mathrm{U} / \mathrm{mL}$; the optimum temperature at $40 \circ \mathrm{C}$ with activity $8.017 \mathrm{U} / \mathrm{mL}$; maximum carbon source at a concentration of $15 \%(\mathrm{~b} / \mathrm{v})$ with activity $7.517 \mathrm{U} / \mathrm{mL}$; and the optimum source of nitrogen with a concentration of $0.17 \%(\mathrm{~b} / \mathrm{v})$ with an activity of $4.815 \mathrm{U} / \mathrm{mL}$.
\end{abstract}

Keywords: Bacillus subtilis, xylanase, characterization 


\section{Introduction}

The bleaching process is one of the treatments performed to remove residual lignin and extractive substances. This process is carried out to improve the quality of the pulp, namely increasing the brightness, cleanliness, and brightness stability of the pulp. The whitening quality of the pulp can be judged by the brightness and viscosity of the pulp that has been bleached. Currently, most of the pulping technology used in the pulp and paper industry in Indonesia is the kraft process or the sulfate process, which is the most widely used process in the world, meanwhile, bleaching uses a lot of $\mathrm{Cl}_{2}$ (chlorine).

The use of chlorine in pulp bleaching is a serious problem because it causes environmental problems. The negative impact caused is the discharge in the form of Adsorbable Organic Halogen (AOX) chlorine compounds in the form of dioxins, furans, and halogens which have been used around the world as parameters that state the level of dangerous pollution. Another bleaching technology that does not use chlorine is biobleaching using fungi and the use of enzymes. In the biobleaching process, the enzymes used are hemicellulose (xylanase and mannose). Several studies have reported the use of enzymes as pulp bleaching can increase whiteness and reduce the consumption of chemicals significantly.

The addition of xylanase to the pre bleaching process can increase the COD value but significantly reduce the AOX value (Septianingrum et al., 2011; Sugesty et al., 2015). Furthermore, Sugesty, et al. (2015) stated that the quality of dissolving pulp from the results of bleaching using xylanase is higher than using oxygen and meets the requirements of the SNI 0938: 2021 specification. Medonna et al. (2013) reported that xylanase enzyme can be used to purify $\alpha$-cellulose in palm fronds with the best conditions obtained at a temperature of $60{ }^{\circ} \mathrm{C}$, time of 90 minutes, an enzyme volume of $3 \mathrm{~mL}$, and a $\mathrm{pH}$ of 6 with a cellulose value of $97.55 \%$.

Xylanase (endo-beta-1,4-xylanase, E.C. 3.2.1.8) is a group of enzymes that functions to break xylan bonds into simpler compounds in the form of oligosaccharides or xylose. Xylanase is widely used in the industrial world, including the paper, syrup, sugar, pharmaceutical, animal feed, and food industries. In pulp bleaching, the use of xylanase is preferred at the beginning of the process (fungal pretreatment) because this enzyme functions as a facilitator for the bleaching process by breaking the xylose bonds in the xylan chain resulting in the breaking of the remaining lignin and cellulose bonds. This xylanase enzyme is easy to obtain, does not require a mediator and its application in industry is easy, that is, it only adds one more stage without changing the existing process.

Bacillus subtilis is a bacterium that can produce xylanase enzymes. Users of Bacillus subtilis to produce xylanase are still not widely used because in general these bacteria are used to produce proteases in industry. Bacillus is an organism that is often used because it has several advantages, namely, it is easy to grow, is nontoxic, the substrate used is relatively cheap, can survive high temperatures, does not produce metabolic compounds, and produces large amounts of extracellular protein.

Utilization of xylanase isolated from Bacillus subtilis for industrial purposes, especially in paper bleaching must pay attention to the characteristics of the enzyme. The parameters used to determine the characteristics of enzymes, in general, are $\mathrm{pH}$, temperature, incubation time, $\%$ carbon and $\%$ nitrogen. This parameter determines the activity of the enzyme that will be used as a biobleaching agent.

The objective of this research is to identify the characteristics of the xylanase enzyme produced from Bacillus subtillis based on parameters of $\mathrm{pH}$, temperature, incubation time, $\%$ carbon, and $\%$ nitrogen, so it is hoped that knowing its characteristics can be used as a biobleching agent for paper/pulp.

\section{Research Methods}

The characterization of the xylanase enzyme was carried out using the CRD method (completely randomized design) which consisted of determining $\mathrm{pH}$, temperature, carbon source concentration, and nitrogen source concentration on the activity of the xylanase extract isolated from Bacillus subtillis. The optimum $\mathrm{pH}$ determination was carried out with a variation of $\mathrm{pH} 4.0 ; 5.0 ; 6.0$; $7.0 ; 8.0$; and 9.0. Determination of the optimum temperature with temperature variations of $30 ; 35$; $40 ; 45$; and $50{ }^{\circ} \mathrm{C}$. Determination of the optimum incubation time with time variations of $10,20,30$, 40 , and 50 minutes. The carbon source used is sucrose with various concentrations of $5,10,15$, 20 , and $25 \%$. While the nitrogen sources used were $\left(\mathrm{NH}_{4}\right)_{2} \mathrm{SO}_{4}$ with a concentration of $0.08 ; 0.17 ; 0.26$; 0.35 ; and $0.44 \%$. 
Preparation of Solid Media

Bacterial growth using agar solid media to rejuvenate the pure culture of Bacillus subtilis made of $0.25 \mathrm{~g}$ peptone; $0.02 \mathrm{~g} \mathrm{KH}_{2} \mathrm{PO}_{4} ; 0.03 \mathrm{~g}$ $\mathrm{CaCl}_{2} ; 0.14\left(\mathrm{NH}_{4}\right)_{2} \mathrm{SO}_{4} ; 0.03 \mathrm{~g} \mathrm{MgSO}_{4} .7 \mathrm{H}_{2} \mathrm{O} ; 0.1 \mathrm{~g}$ of yeast extract; and $0.5 \mathrm{~g}$ of pectin. The pure culture was put into a beaker that was adjusted to $\mathrm{pH} 6.0$ by adding $5.0 \mathrm{~mL}$ of citrate buffer solution, after which $1.5 \mathrm{~g}$ of agar was added. The solution is added with distilled water to a volume of $100 \mathrm{~mL}$. The mixture is heated to a boil. Take $4 \mathrm{~mL}$ of the solution, put it in a test tube, then cover it with a cotton ball and sterilize it in the autoclave at a temperature of $121^{\circ} \mathrm{C}$, the pressure of $15 \mathrm{Psi}$, for 20 minutes. After 20 minutes remove the tube and store it on a slant.

\section{Pure Culture Rejuvenation}

The rejuvenation of the pure culture of Bacillus subtilis was carried out in solid media for slant agar which was made in the previous experiment. Take the pure culture of Bacillus subtilis with an ose line, then rub the loop needle on the agar medium by bringing the mouth of the tube containing the agar to the flame. Cover the tube mouth again with sterile cotton, incubate for 72 hours at $30^{\circ} \mathrm{C}$.

\section{Determination of Growth Curves}

The growth curve was determined by measuring the uptake of Bacillus subtilis with a UV-Vis spectrophotometer at a wavelength of 660 nm every 2 hours.

\section{Preparation of Liquid Media}

The xylanase enzyme was grown in a liquid medium made by mixing $1.25 \mathrm{~g}$ peptone;

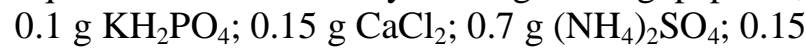
$\mathrm{g} \mathrm{MgSO}_{4} .7 \mathrm{H}_{2} \mathrm{O} ; 0.5 \mathrm{~g}$ of yeast extract; and $2.5 \mathrm{~g}$ of pectin. The mixture is put in a beaker that is adjusted to $\mathrm{pH} 6.0$ by adding $25 \mathrm{~mL}$ of $\mathrm{pH} 6.0$ citrate buffer as much as $25 \mathrm{~mL}$. Then add distilled water until the volume is $500 \mathrm{~mL}$. The mixture is stirred and heated to a boil. Take $100 \mathrm{~mL}$ of the solution, put it in an Erlenmeyer cover with a cotton swab, and sterilize it in an autoclave for 20 minutes at a temperature of $121^{\circ} \mathrm{C}$, a pressure of 15 Psi.

\section{Preparation of inoculum}

Bacillus subtilis that have grown and are 1 day old are taken as much as one eye ose needle inserted into $100 \mathrm{~mL}$ of liquid media that has been prepared beforehand. Then it was incubated on a shaker at room temperature with a rotating speed of $125 \mathrm{rpm}$ for 18 hours.

\section{Production and Isolation of Xylanase Enzyme from Bacillus subtilis}

Take $10 \mathrm{~mL}$ of inoculum solution, put it in $100 \mathrm{~mL}$ of sterile liquid media, and incubate it for 24 hours at room temperature using a shaker at a speed of $100 \mathrm{rpm}$. Add $5 \mathrm{~mL}$ of a citrate buffer solution with a $\mathrm{pH}$ of 6.0 . Then the media was centrifuged for 20 minutes at a speed of $3000 \mathrm{rpm}$ at room temperature. After 20 minutes the centrifugation was stopped, the supernatant phase in the upper layer containing the crude xylanase extract was separated from the precipitate and used for determining the optimum conditions.

\section{Determination of the Optimum $\mathrm{pH}$}

Prepare 6 test tubes each filled with $1.0 \mathrm{~mL}$ of $1 \%(\mathrm{w} / \mathrm{v})$ xylan substrate, then take 4 test tubes, each added with $1.0 \mathrm{~mL}$ of citrate phosphate buffer at $\mathrm{pH} 4.0 ; 5.0 ; 6.0$; and 7.0. The other two tubes were filled with $1.0 \mathrm{~mL}$ of Tris- $\mathrm{HCl}$ buffer at $\mathrm{pH} 8.0$ and 9.0. Furthermore, all tubes were sterilized in an autoclave for 20 minutes. After 20 minutes, add $1.0 \mathrm{~mL}$ of xylanase crude extract and incubate for 30 minutes at a temperature of $50{ }^{\circ} \mathrm{C}$. Reducing sugar content was analyzed by spectrophotometry using DNS reagent (Dinitrosalicylate).

\section{Determination of the Optimum Temperature}

Provide 5 test tubes, each filled with $1.0 \mathrm{~mL}$ of $1 \%(\mathrm{~b} / \mathrm{v})$ xylan substrate, then conditioned to the optimum $\mathrm{pH}$ in the previous study. Sterilize the test tube that has been filled with pectin for 20 minutes in an autoclave. Add $1.0 \mathrm{~mL}$ of xylanase extract to each tube, then each tube was incubated sequentially at temperatures of $30,35,40,45$, and $50{ }^{\circ} \mathrm{C}$. Reducing sugar content was analyzed by spectrophotometry using a DNS reagent.

\section{Determination of the Optimum Carbon Source}

Provide 5 test tubes, each filled with $1.0 \mathrm{~mL}$ of $1 \%(\mathrm{~b} / \mathrm{v})$ xylan substrate, add sucrose with various concentrations of $5,10,15,20$, and 25 $(\% \mathrm{~b} / \mathrm{v})$. Then the tube was conditioned to the optimum $\mathrm{pH}$ and temperature in the previous research. Sterilize the test tube that has been filled with xylan for 20 minutes in an autoclave. Add 1.0 $\mathrm{mL}$ of xylanase extract to each tube, then each tube was incubated sequentially at the optimum $\mathrm{pH}$ and temperature from the previous treatment. Reducing sugar content was analyzed by spectrophotometry using a DNS reagent.

\section{Determination of the Optimum Nitrogen Source}

Provide 5 test tubes, each filled with $1.0 \mathrm{~mL}$ 
of $1 \%(\mathrm{~b} / \mathrm{v})$ xylan substrate, add $\left(\mathrm{NH}_{4}\right)_{2} \mathrm{SO}_{4}$ with varying concentrations of $0.00 ; 0.17 ; 0.26 ; 0.35$; $0.44(\% \mathrm{~b} / \mathrm{v})$. Then the tube was conditioned to the optimum $\mathrm{pH}$ and temperature in the previous research. Sterilize the test tube that has been filled with xylan for 20 minutes in an autoclave. Add 1.0 $\mathrm{mL}$ of xylanase extract to each tube, then each tube was incubated sequentially at the optimum $\mathrm{pH}$ and temperature from the previous treatment. Reducing sugar content was analyzed by spectrophotometry using a DNS reagent.

\section{Making Standard Curves for Reducing Sugar}

Prepare 5 test tubes, each filled with $1.0 \mathrm{~mL}$ of standard glucose solution with concentrations of $500,1000,1500,2000$, and $2500 \mathrm{mg} / \mathrm{L}$. Each tube was added with $1.0 \mathrm{~mL}$ of citrate buffer and $2.0 \mathrm{~mL}$ of control reagent. Cover the mouth of the tube with aluminum foil, heat it in a boiling water bath for 5 minutes, and let it cool under running water for 15 minutes. Once cool, put it in a $25 \mathrm{~mL}$ volumetric flask, add distilled water to the limit mark. Blank solution using distilled water with the same treatment. The solution was measured by a spectrophotometer at a wavelength of $540 \mathrm{~nm}$.

\section{Result and Discussion}

\section{Determination of Growth Curves}

Growth curves contain information about the growth phases of Bacillus subtilis. In this case, the determination of the growth phase is carried out in an incubation period of every 2 hours, from the $0^{\text {th }}$ minute to the $28^{\text {th }}$ minute.

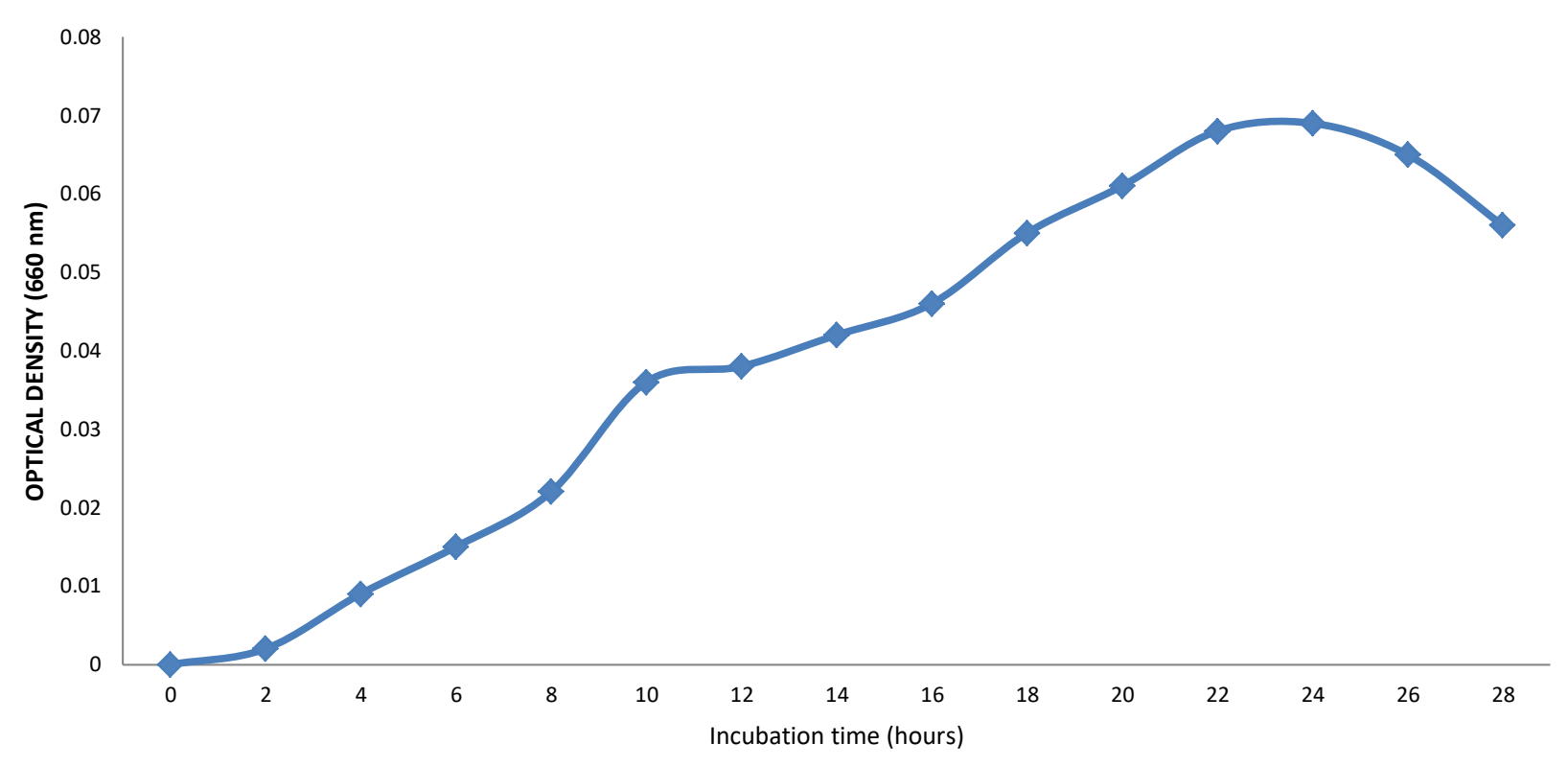

Figure 1. Growth Curve for Bacillus subtilis

Based on the growth curve in Figure 1, shows that at 0 to 2 hours Bacillus subtilis undergoes an early growth phase (lag phase). In this phase, the bacteria experience an increase in macromolecular components, metabolic activity, susceptibility to chemical substances, and physical factors. Furthermore, the growth at 2 to 20 hours is an exponential phase, in this phase the mass and volume of cells increase. Balanced bacterial growth, the rate of increase is expressed by natural exponential functions. At the 20th to 22nd hours Bacillus subtilis reaches the end of the exponential phase so that the growth rate begins to decline. At 22 to 26 hours Bacillus subtilis has entered a stationary phase. After 26 hours the number of living cells remained constant for different periods depending on the bacteria, but eventually died and decreased the bacterial population.

\section{Xylanase characterization}

Xylanase characterization was carried out to determine the optimum conditions for xylanase activity which included $\mathrm{pH}$, temperature, carbon source concentration, and concentration of nitrogen sources.

\section{Determination of the Optimum $\mathrm{pH}$}

In determining the optimum $\mathrm{pH}$, it is known that xylanase activity increases with increasing $\mathrm{pH}$ up to $\mathrm{pH} 7$, at higher $\mathrm{pH}$ the activity decreases (Figure 2). The optimum $\mathrm{pH}$ is the $\mathrm{pH}$ where the enzyme activity is maximum. This condition is needed by the enzyme to activate all the enzymes that bind to the substrate and turn them into products. The xylanase activity of the sequences at $\mathrm{pH} 4,5,6,7$, and 8 was $0.931 ; 1,125 ; 1,258 ; 1,561$; and 0.497 . 


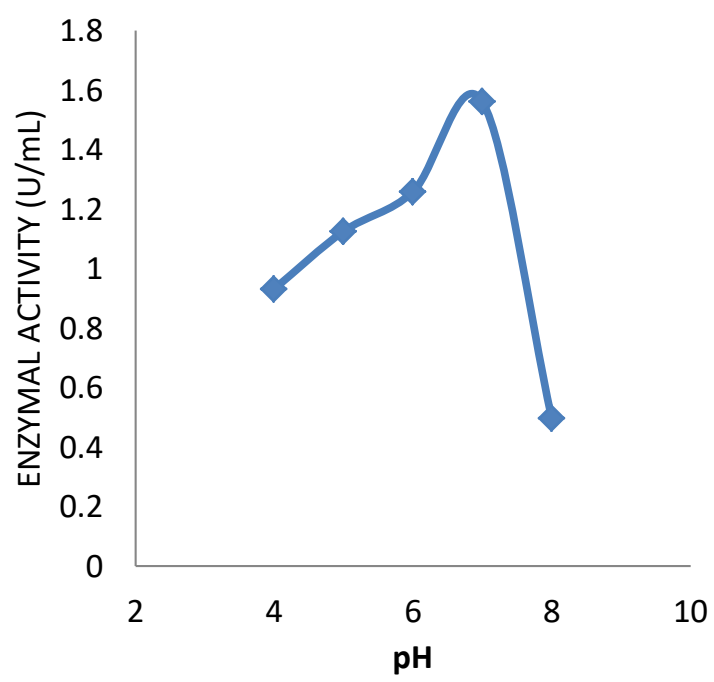

Figure 2. The curve for Determining the Optimum Activity of Xylanase Enzyme Based on pH Variations

Xylanase works best at neutral $\mathrm{pH}$ (Figure 2). At alkaline $\mathrm{pH}$, namely $\mathrm{pH} 8$, xylanase has a sharp decrease in activity due to denaturation. The results of this study are slightly different from the results of research by Ardiyansyah et al. (2014) who reported that the optimum pH of xylanase from Bacillus subtilis is pH 8 with a maximum activity of $5.461 \mathrm{U} / \mathrm{mg}$. Another study reported by Septianingrum et al (2011) found that xylanase from Bacillus circulars worked in the $\mathrm{pH}$ range $8.0-10.5$ with the highest activity at $\mathrm{pH} 8.5$, namely $8.80 \mathrm{U} / \mathrm{mL}$. Changes in $\mathrm{pH}$ can affect the activity of the enzyme because the charge of the functional groups contained in the enzyme, namely carbohydrate and amino acid functional groups, changes in terms of the level of ionization. At $\mathrm{pH}$ conditions below the optimum $\mathrm{pH}$, the concentration of $\mathrm{H}^{+}$and $\mathrm{OH}^{-}$ions can affect the carboxyl (-COOH) functional group from the xylanase active side, consequently the xylanase active side cannot bind to the substrate, and the enzyme-substrate complex that is formed is not optimal.

\section{Determination of the Optimum Temperature}

Based on the determination of the optimum temperature of xylanase at $\mathrm{pH} 7$, it is known that increasing the temperature will increase the xylanase activity to the optimum temperature, which is $40{ }^{\circ} \mathrm{C}$. The enzyme activity based on temperature variations of $30,35,40,45$, and $50{ }^{\circ} \mathrm{C}$ was 8,$943 ; 9,234 ; 9,324 ; 8,645$; and $8,015 \mathrm{U} / \mathrm{mL}$.

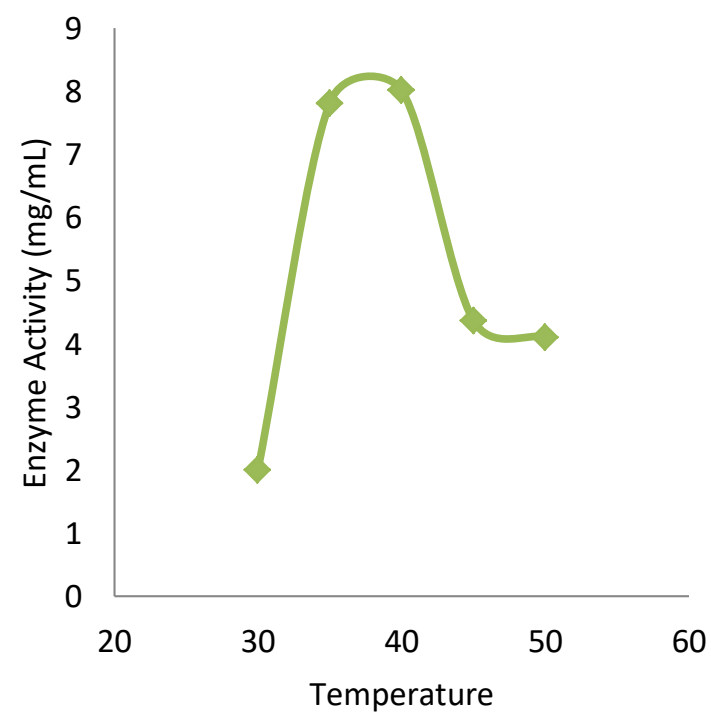

Figure 3. The curve of xylanase enzyme activity based on temperature variations

The optimal temperature is the best temperature required for enzymes to carry out enzymatic reactions to produce products. The optimum temperature of xylanase is known at a temperature of $40^{\circ} \mathrm{C}$ with an activity of 9.324 $\mathrm{U} / \mathrm{mL}$ (see Figure 3). Increasing temperature results in increased enzyme activity. This is because the increase in temperature will increase the kinetic energy so that the collision between the enzyme and the substrate will easily occur. The collision that occurs will form an increasing enzyme-substrate complex which in turn will produce more and more products. The xylanase activity decreased drastically at a temperature of $45^{\circ} \mathrm{C}$. This happens because the enzymes are denatured. At temperatures above the optimum temperature the enzyme slowly changes its conformation, this makes it difficult for the substrate to enter the active site of the enzyme.

\section{Determination of the Optimum Carbon Source}

The carbon source used in this study was sucrose with various concentrations of $5,10,15$, 20 , and $25 \%$. Based on the research results, it is known that xylanase activity based on variations in carbon sources at the optimum temperature of 40 ${ }^{\circ} \mathrm{C}$ is 5,$335 ; 5,136 ; 6,518 ; 5,512$; and 4,676 $\mathrm{mg} / \mathrm{mL}$. The addition of sucrose as a carbon source at concentrations of 5 and $10 \%$ did not have a significant effect on xylanase activity. The highest activity was at a concentration of $15 \%$ sucrose with xylanase activity reaching $7.517 \mathrm{mg} / \mathrm{mL}$, while the lowest activity was at a concentration of $25 \%$.

The addition of the concentration of carbon sources will increase the enzyme activity up to a certain point, but when the concentration is increased again there will be a decreased activity. 


\section{Sulistiana, Anggraini, \& Agustina}

This indicates that the xylanase is saturated with $15 \%$ sucrose addition so that after reaching the optimum point, the addition of sucrose in any concentration will reduce xylanase activity. This is in line with the research of Zuhri et al. (2013) who reported that the optimum concentration of carbon sources was $1.5 \%$ with a maximum protease activity of $0.108 \mathrm{U} \mathrm{VmL}$. Carbohydrates in the medium can cause an increase in the growth of microorganisms, but if they are in excess amounts, they will harm enzyme production. Carbon sources with an excess concentration exceeding the optimum concentration can act as a catabolite repressor which results in a decrease in enzyme production.

\section{Determination of the Optimum Nitrogen Source}

Not only carbon sources but also the concentration of nitrogen sources affect xylanase activity. The nitrogen sources used were $\left(\mathrm{NH}_{4}\right)_{2} \mathrm{SO}_{4}$ with a concentration variation of 0.08 ; $0.17 ; 0.26 ; 0.35$; and $0.44 \%$. The results showed that the enzyme activity based on variations in the concentration of nitrogen sources at $40{ }^{\circ} \mathrm{C}$ was $3.12 ; 4,815 ; 3,518 ; 3,651$; and 2,017 U/mL.

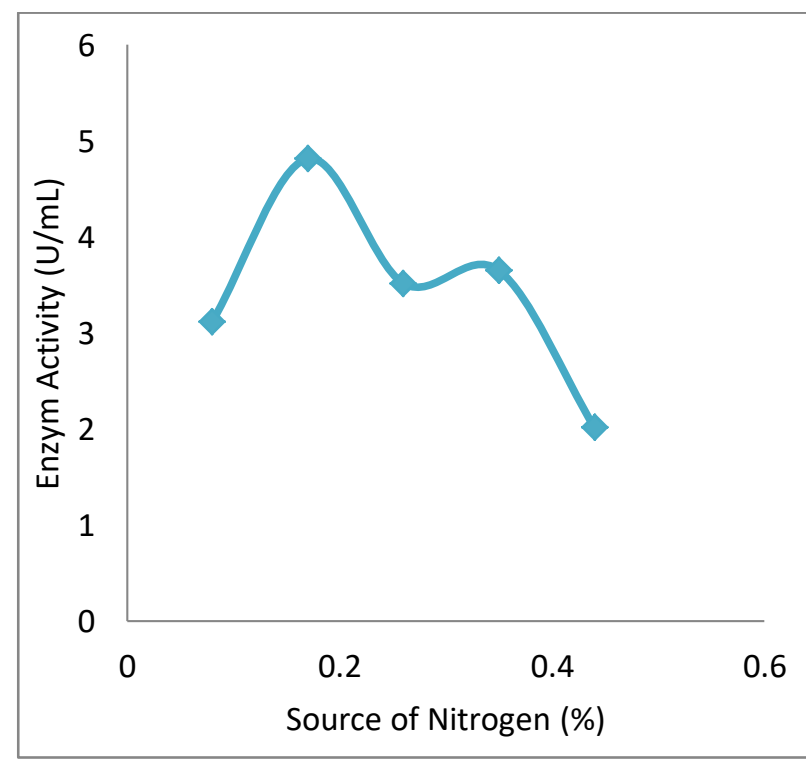

Figure 4. Xylanase activity is based on variations in the concentration of nitrogen sources.

The addition of $\left(\mathrm{NH}_{4}\right)_{2} \mathrm{SO}_{4}$ as a nitrogen source with a concentration of $0.17 \%$ gives the highest activity in xylanase, namely $4.815 \mathrm{U} / \mathrm{mL}$ (see Figure 4). The lowest xylanase activity was the addition of a nitrogen source of $0.44 \%$ with an activity of $2.017 \mathrm{U} / \mathrm{mL}$. The addition of carbon and nitrogen will affect xylanase production, so the addition of $0.17 \%$ (NH4) 2SO4 as a nitrogen source and $15 \%$ sucrose as a carbon source is the best treatment in inducing xylanase so that xylanase activity is high. The nitrogen source is needed for cell growth, while the carbon source is needed to increase the biosynthetic energy of microorganisms.

\section{Reducing Sugar Standard Curve}

In determining xylanase activity, reducing sugar levels were measured. Sugar solutions for standard curves were prepared using glucose with concentrations of 500,1000,1500, 2000, and 2500 $\mathrm{mg} / \mathrm{L}$. 500, 1000, 1500, 2000, and $2500 \mathrm{mg} / \mathrm{L}$. Table 1 shows the results of measurements using a Uv-Vis spectrophotometer. Furthermore, the data is transformed into a graphic in Figure 5.

Table 1. Glucose Absorbance Data in Determination of Standard Curve for Reducing Sugar

\begin{tabular}{ccccc}
\hline $\begin{array}{c}\text { Glucose } \\
\text { concentration } \\
\text { (mg/L) }\end{array}$ & $\mathbf{A}_{\mathbf{1}}$ & $\mathbf{A}_{\mathbf{2}}$ & $\mathbf{A}_{\mathbf{3}}$ & $\begin{array}{c}\mathbf{A}_{\text {rata- }} \\
\text { rata }\end{array}$ \\
\cline { 2 - 5 } & 0,2375 & 0,2376 & 0,2374 & 0,2375 \\
500 & 0,4086 & 0,4084 & 0,4084 & 0,4085 \\
1000 & 0,6136 & 0,6135 & 0,6134 & 0,6135 \\
1500 & 0,7536 & 0,7537 & 0,7537 & 0,7537 \\
2000 & 0,8684 & 0,8683 & 0,8682 & 0,8683 \\
2500 & & & &
\end{tabular}

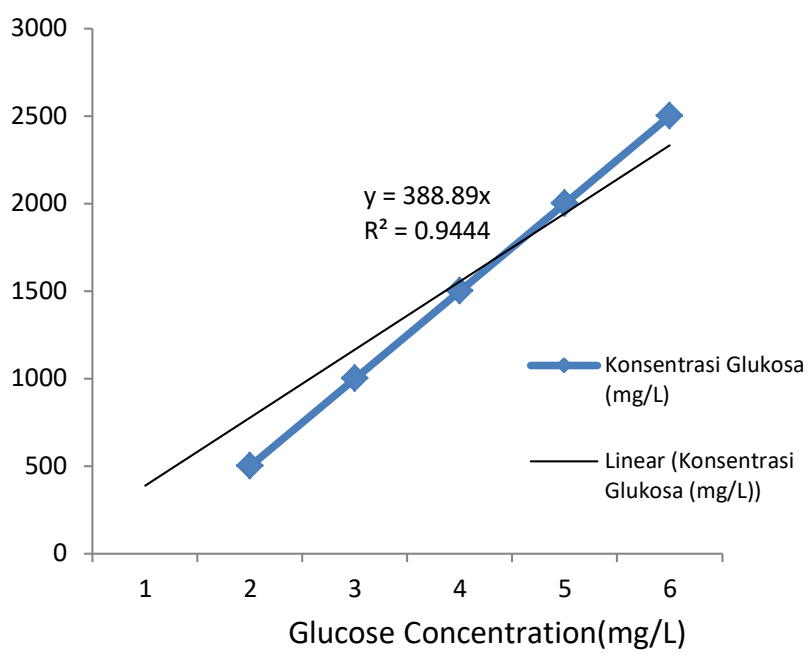

Figure 5. Standard Curve of Reducing Sugar

From Figure 5, a mathematical equation is obtained, namely, $\mathrm{x}=\mathrm{y} / 388.8$ where $\mathrm{x}$ is the concentration of glucose, and $y$ is the absorbance of glucose with a wavelength of $540 \mathrm{~nm}$.

\section{Conclusion}

From the characterization results of the determination of $\mathrm{pH}$, temperature, carbon source, and nitrogen xylanase source from Bacillus subtilis, it is known that the optimum conditions for xylanase are at $\mathrm{pH} 7$ with a maximum activity of $5.085 \mathrm{U} / \mathrm{mL}$; the optimum temperature at $40 \mathrm{oC}$ with activity $8.017 \mathrm{U} / \mathrm{mL}$; maximum carbon source 
at a concentration of $15 \%(\mathrm{~b} / \mathrm{v})$ with an activity of $7.517 \mathrm{U} / \mathrm{mL}$; and the optimum source of nitrogen with a concentration of $0.17 \%(\mathrm{~b} / \mathrm{v})$ with an activity of $4.815 \mathrm{U} / \mathrm{mL}$.

\section{References}

Ardiansyah, Y. T., Mulyani, N. S., \& Sarjono, P. R. (2014). Isolasi dan Karakterisasi Enzim Xilanase dari Bacillus Subtilis pada Media Nutrient Broth dengan Penambahan Xilan Hasil Isolasi Jerami Padi. Jurnal Kimia Sains dan Aplikasi, 17(3),

9599. https://doi.org/10.14710/jksa.17.3.9599

Ruiz-Arribas, A., Fernández-Abalos, J. M., Sánchez, P., Garda, A. L., \& Santamariá, R. I. (1995). Overproduction, purification, and biochemical characterization of xylanase (Xys1) from Streptomyces halstedii JM8. Applied and environmental microbiology,61(6), 2414-2419.

https://doi.org/10.1128/AEM.61.6.24142419.1995

Batubara, Ridwan. (2006). Teknologi Bleaching Ramah Lingkungan. Fakultas Kehutanan Universitas Sumatera Utara.

Bourbonnais, R., Paice, M. G., Freiermuth, B., Bodie, E., \& Borneman, S. (1997). Reactivities of various mediators and laccases with kraft pulp and lignin model compounds. Applied and environmental microbiology, 63(12), 4627-4632. https://doi.org/10.1128/AEM.63.12.46274632.1997

Hatmanti, A. (2000). Pengenalan Bacillus spp. Jurnal Oseana, 25 (1) : 31-41. http://oseanografi.lipi.go.id/dokumen/ose ana $\operatorname{xxv(1)31-41.pdf}$

Lehlinger, A. L. (1990). Dasar-Dasar Biokimia. Alih Bahasa: Maggy Thenawidjaya. Erlangga : Jakarta.

Putri, M. F., Sari, D.P., Caesari, A., \& Miranda, G. (2013). Biobleaching Pelepah Sawit sebagai Bahan Baku Pembuatan Nitroselulosa Menggunakan Enzim Xylanase. Pekan Ilmiah Nasional PKM tahuh

2013.

https://www.neliti.com/id/publications/17 1147/biobleaching-pelepah-sawit-

sebagai-bahan-baku-pembuatannitroselulosa-menggunakan. Diakses pada tanggal 7 Sepetember 2020.

Richana, N., Irawadi, T. T., Nur, A. \& Syamsu, K. (2008). Isolasi Identifikasi Bakteri Penghasil Xilanase serta Karakterisasi Enzimnya. Jurnal AgroBiogen, 4 (1): 2434.

http://dx.doi.org/10.21082/jbio.v4n1.200 8.p24-34

Septianingrum, K. \& Sugesty, S. (2013). Pengaruh Penambahan Xilanase Pada Proses Pemutihan Elemen Sistem Chhlorine Free (ECF). Jurnal Selulosa, 3 (1): 15-26. http://dx.doi.org/10.25269/jsel.v3i01.40

Septianingrum, K. \& Apriana, C. (2011). Produksi Xilanase Dari Tongkol Jagung dengan Sistem Bioproses Menggunakan Bacillus circulans untuk Pra-pemutihan Pulp. Jurnal Riset Industri, 5 (1): 87-97. http://ejournal.kemenperin.go.id/jri/articl e/view/84

Sugesty, S., Kardiansyah, T., \& Pratiwi, W. (2015). Penggunaan Xilanase Pada Pemutihan Dissolving Pulp Acacia crassicarpa. Jurnal Selulosa, 4 (2): 99-106. http://dx.doi.org/10.25269/jsel.v5i02.80

Susanti, E. (2012). Isolasi dan Karakterisasi Protease dari Bacillus subtilis 1012M15. Biodiversitas, 4 (1) : 12-17. https://biodiversitas.mipa.uns.ac.id/D/D0 401/D040103.pdf

Susanti, R. \& Febina, F. (2017). Teknologi Enzim. Yogyakarta: CV Andi Offset.

Zuhri, R., Agustien, A., \& Rilda, Y. (2013). Pengaruh Konsentrasi Sumber Karbon dan Nitrogen Terhadap Produksi Prorease Alkali dari Bacillus sp. M1,2,3 Termofilik. Prosiding Semirata FMIPA Universitas Lampung, 2013, 1 (1): 273277

https://jurnal.fmipa.unila.ac.id/semirata/a rticle/view/620 